斩解釋還不够，隹該加以提高。對於猪睢和猪丹 海的防治，應該以技術力量與行政力量相配合， 劃足疫區，擬定防治法規，從改善飼養管理入手， 和配合防疫來撲隇。對防治猪瘟和猪刃表的疫萌 製造使用, 應該繼續的研究。關於馬鼻唒的問題, 由於互助合作運動的發展, 馬匹集中, 傅染迅速,

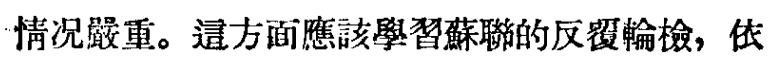
靠畫衆進行防治, 及時隔離, 防止疫情擴大。試 驗研究方面應加緊撿疼技術和疫计研究, 從多方

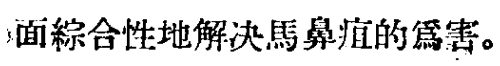

狺次的裳業科學各專門學會學術討論會是有 成績的。首先, 這次討論會鿓微了國家過渡時湖 總路線的精神，討論會得到了中央農業部和中國 :科學院的支持，因此討論的問題都是 $[$ 目前的和將 來的生產上的重要問題。例如在宸學組環繞棺糧 增産的要求進行了馀論, 植病和昆踏組討論了病

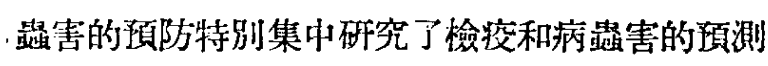
預報工作問題，土壤組圍繞着討論了提高士壤肥

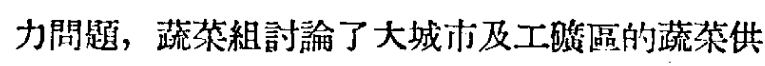
應問題，果樹組討論了提高單位西皘產量品質以 及今後發展的問題, 音牧鄂醫組討論了家畜的繁 殖和疾病的防治問題等。各組所討論的問題對國 目經淙的發展和人民生活的提高, 都有着重要意 義。在這些問題的討論中, 時常有不少具體的建議 提出, 供給生座單位和行政部門在解决這些問題 時作篇參考。關於疏荣的供應問題上，根據討論 會的意兒，中央農業部生裳總局、北京方農林局、
華北農業科學研究所、北京農業大學淮備組織力 量, 調查北京郊區早熟的裁培方法, 以及京郊合 作社山小䤄皘生産到大面皘生產中所發生的問 題。中次農業部生產總局淮備在䢝二次討論監碱土

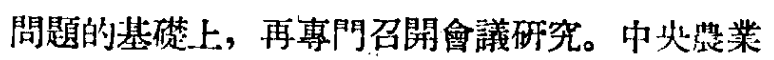
部農政總局準備在今年笶訂,植物病路害检疫的初 步法規, 並蕉備與對外留易部商議检疫機構的調 整和分工等問題。

由於參加討論會的同志來自行政、研究、教 有、生產等不同工作岗位, 大家能從各個的度提 出問題相互交流工作經驗。例如高等學校的教師 們在討論會上了解到不少農業生產中所碰到的現

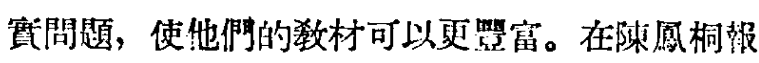
告他們農村工作的收穫後, 北京農業大學亦淮備 派一部分敎師與學生, 到河北、江西雨省晨村去進 行生産虽畉。

經過了塄次討論會，詐多科學工作者交流了 經驗，建立了聯系，如鄂筍組討論到了好多單位 正在共同要解决的馬鼻疸等病，經過了討論建立 了今後聯系的關係。利學工作者通過討論會中 的許多具體事例，進一步明確了自己工作的意義 以及與總路線的閔係。如果樹工作者知道提高果 樹座量, 既可進一步滿足人民需要, 又可多換取工

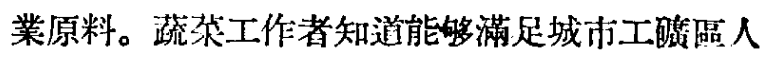
民對疏荣的需要，也就是對國家工業化的支持。 這一切，都給每一個到會者以很大的鼓舞。

(本 刊)

\title{
中國紡織工程學會擧行成立大會
}

中國紡織工程學會在今年 2 月 19 日至 25 日 在北京舉行了第一次全國會員代表大會。出席和 列席大會的各地區代表共 60 多人。

這次大會是結合中央人民政府紡織工業部全 國國營紡織廠廠長會議召開的。全體代表在大會 前後都參加了廠長會議, 明確了紡織工業的發展 方向和當前的中心工作, 提高了代表們進行學矿 研究的信心。

在開幕式上，中華全國自然科學專門學會聯 合會副主席曾昭掄和中央人民政府紡織工業部代 表都到會講話。
科學通報
中國紡織工程學會䇾借委員會理事長陳維䅡 在會上作了關於學會今後方針任稀的報告。他說:

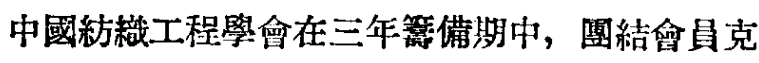
服困難，恢復和發屡生產，學晳蘇聯先進經驗， 開展合理化建議, 總結先進工作法等各方面都起 了一定的作用。今後的任務是遵循國家在過渡特 期的總路綫，在整頓、勒固學會工作的基礎上， 展開科學研究, 改進紡織技術, 不斷地提高我們 的科學技術水平, 篇紡織工業的建設貢铁更多更 大的力量。因此, 我們要號召全國紡織技術工作 者, 努力學習馬克思列察主義和蘇聯先進科學技

\section{4 月號}

- 43 - 


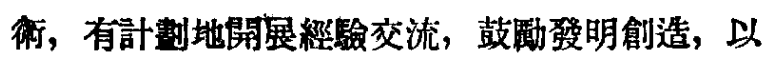
配合紡樴工業磪展的要求。

大會期間，代表們還聽取了上海地區開展會 務工作的經驗介紹和各地區的工作营報。上海地 剾的會務工作，在最初兩年由於始終停留在整理 組織、建立組織和辡固組織的階段上，没有很好地 結合學術研究等業務工作, 因此會員們普遍對會 務不開心，學會也因篇得不到會員的關心和支持 搞不出什㦄工作。直到1953年 3 月間, 負責會教工 作的理事們兽重研究了開展今後工作的問題, 明 確了專門學會結合學術研究工作的重姴性, 工作 才有了㙷著的改進。他椚出版了“紡織學會通訊”; 藇辦了學術筴座; 先後成立了清花、梳棉、悠粗、 精紀、準備、棉織、試驗等 7 個專業的 9 個小組， 進行學術討論; 組織參萑, 吸收先進的操作過程 和技術經驗，亚考察位良的工廠設诸; 協助生産
部門，設立聯合初級業餘紡織學校; 設立了專業 俄文閔詇速成理; 此外還粗樴會員參加各種重大 的社會活動。這些工作對於提高會員技術水平和 工作啨極性, 加强會員與拔術工人之間的聯系與 團結以及摭大學會的影響等，都起了一定的作 用，取得了一定的成績。上海地蛋工作經驗介絽 給各地代表以很大的幫助。

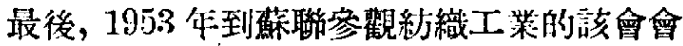

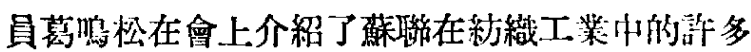
重要改進。大會還邀請蘇聯專家卡薙斯基仁了“關 於蘇聯紡織技術領域的重大成就與䋓織僘的改造 問題”的專題報告, 使到會代表進一步朋確了絖織 工業技術發展的方向和遠景。

大會並通過了“中國紡織工程學會章桯”，選 出了第一屆全國理事會理事。

\section{（本 刊）}

\section{中央地質部召開有色金屬專業會議}

有色金虽碈産是冶金工業的重要原料, 在重 工業建設中，有色金屬佔着非常重要的地位。

第一個五年計劃建設開始後，中夾地賢部於

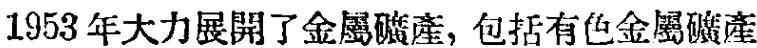
的勘探工作，獲得了很大成績。一年乘，經過了 有限的普查和局部的勘探，對葉些新型有價佔的 睡床也有了新的認識與初步評價，篇今年的勘探 工作打下了很好的基稳。但總的說來，地筫勘探 工作還不能全面地滿足國家經济建设的當前需要 和將來的要求。目前, 地犋工作上的薄弱環節, 不僅表現在然料資源的勘探方面，而且在有色金 屬資源芴探方面，特别是某些需要量不大但篇冶 金工業所必需的酸産資源方面，還不能滿足國家 的要求。

今年有色金風資源的炡探在全部地質散探工 作中佔着相當重要的位置。今年的任预是E大的， 撂探項目比去年加多了，酸量要求方面也此去年

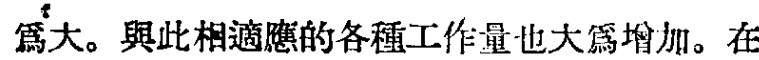
重點勘探的同時，還要卧開大規模普企工作，篇

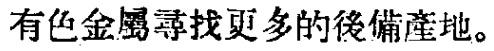

今年的任肦是鞑巨而光柴的。地翼工作者們 必須如期完成或提前完成計劃要求, 以保登有出

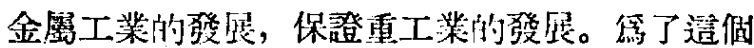
目的，中央地啠部在 1954 年2月 15-27 日召阙

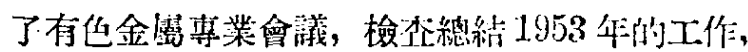
研究喐置今年的工作，進行一次有系統的有色金

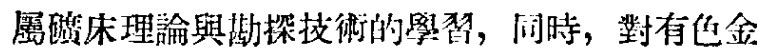
䐂的勘探透景作一次此較光分的研究與敦論, 以 便進一步提淌今後的勘探工作。

出席這次會潼的有中尖地資部及各地算局的

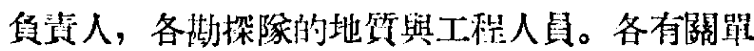

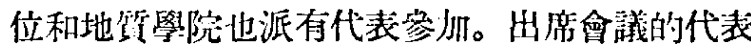
共二百餘人。

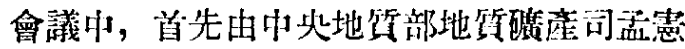

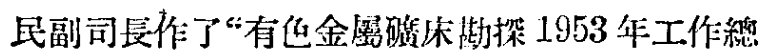
結及 1954 年的任吩”的赫少。他在岗定了 1953 年的工作成績之後, 提出了勘探工作中的經驗及 存在問題。在磪床評價方面, 他指出, 由於工作

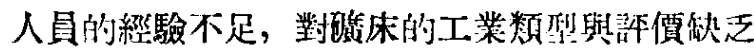

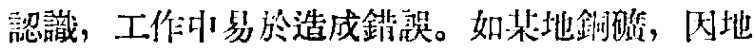

